\title{
ANALISIS KEBERLANJUTAN USAHATANI KOPI DI KECAMATAN PANJALU KABUPATEN CIAMIS
}

\author{
ANALYSIS OF SUSTAINABILITY COFFEE FARM IN KECAMATAN PANJALU, \\ KABUPATEN CIAMIS
}

\author{
AZRUL SYACHRULOH ${ }^{1}{ }^{*}$, IWAN SETIAWAN $^{2}$, MUHAMAD NURDIN YUSUF $^{1}$ \\ ${ }^{1}$ Fakultas Pertanian Universitas Galuh \\ ${ }^{2}$ Fakultas Pertanian Universitas Padjajaran \\ *Email: azrulsyahrulloh@gmail.com
}

\begin{abstract}
ABSTRAK
Kecamatan Panjalu termasuk pada kawasan agropolitan di Kabupaten Ciamis karena memiliki pengembangan yang baik dalam sektor pertanian.Salah satu produksi terbesar dalam sektor perkebunan di Kecamatan Panjalu adalah kopi robusta.Penelitian ini bertujuan untuk menganalisis pendapatan usahatani dan praktik usahatani yang berkelanjutan pada petani kopi di Kecamatan Panjalu Kabupaten Ciamis. Penelitian ini menggunakan metode survey dengan sampel penelitian terdiri dari 37 petani. Pengambilan data dilakukan pada bulan April sampai Juni 2020. Data dianalisis menggunakan analisis deskriptif kuantitatif dan deskriptif kualitatif. Hasil penelitian ini menyatakan bahwa Nilai $N P V$ yang diperoleh dari kegiatan usahatani kopi di Desa Kertamandala adalah sebesar Rp7.649.507;-. Nilai $N P V$ diperoleh hasil positif, maka kegiatan usahatani kopi di Desa Kertamandala di tahun ini layak untuk dilaksanakan karena menghasilkan $N P V$ lebih besar dari nol $(N P V>0)$. Regenerasi petani di Desa Keratmandala kurang dan paraktik pertanian organik dalam budidaya kopi Desa Kertamandala Kecamatan Ciamis belum terealisasi sepenuhnya.
\end{abstract}

Kata kunci : keberlanjutan, kopi, usahatani

\begin{abstract}
Panjalu District is included in the agropolitan area in Ciamis Regency because it has good development in the agricultural sector. One of the largest productions in the plantation sector in Panjalu District is robusta coffee. This study aims to analyze farm income and sustainable farming practices in coffee farmers in Panjalu District. Ciamis Regency. This study used a survey method with a sample of 37 farmers. Data were collected from April to June 2020. Data were analyzed using quantitative descriptive analysis and qualitative descriptive analysis. The results of this study state that the NPV value obtained from coffee farming activities in Kertamandala Village is IDR 7,649,507;

-. The NPV value is positive, so the coffee farming activity in Kertamandala Village this year is feasible to be implemented because it produces an NPV greater than zero (NPV>0). The regeneration of farmers in Keratmandala Village is lacking and the practice of organic farming in coffee cultivation in Kertamandala Village, Ciamis District has not been fully realized.
\end{abstract}

Keywords: sustainability, coffee, farming

\section{PENDAHULUAN}

Kopi merupakan komoditas pertanian yang paling akrab dengan masyarakat, mulai dari kalangan ekonomi atas sampai bawah. Hingga saat ini, kopi masih menduduki komoditas andalan ekspor hasil pertanian Indonesia selain kelapa sawit, karet dan kakao. Kopi merupakan salah satu komoditi perkebunan yang diharapkan mampu meningkatkan nilai devisa ekspor Indonesia (Santoso, 2016). 
Menurut Badan Pusat Statistik (2018), Jawa Barat merupakan salah satu provinsi di Indonesia yang termasuk kedalam 10 besar pemilik perkebunan kopi terluas, yakni 41.300 hektar (3,33 persen) dengan produksi sekitar 19.600 ton (2,71 persen). Jika dibandingkan dengan angka permintaan (kebutuhan) konsumsi kopi dari masyarakat Jawa Barat yang mecapai 90.000 ton setiap tahun, makaterlihat jelas kesenjangannya (gap)dengan angka produksinyayang hanya mencapai 19.600 ton pada tahun 2018.

Kabupaten Ciamis merupakan salah satu daerah yang memiliki potensi ekonomi cukup tinggi, terutama dalam sektor pertanian. Oleh karena itu, tidak berlebihan apabila paradigma pembangunan ekonomi di Kabupaten Ciamis dititik beratkan pada keselarasan pengembangan pertanian dengan bertumpu pada pengembangan sumber daya lokal. Perkebunan kopi rakyat menjadi salah satu sub sektor pertanian yang potensial di Kabupaten Ciamis.

Kecamatan Panjalu merupakan salah satu sentra produksi kopi robusta di Kabupaten Ciamis. Namun demikian, jika dilihat dari tingkat produktivitasnya, kopi robusta yang dikembangkan di Kecamatan Panjalu terlihat lebih rendah daripada tingkat produktivitas rata-rata Kabupaten
Ciamis. Namun demikian, Kecamatan Panjalu memiliki angka tertinggi dalam hal luas tanam kopi, bahkan luas tanam kopinya terus meningkat, sehingga dijadikan Desa Agrowisata kopi.

Desa Kertamandala merupakan daerah yang paling banyak mengembangkan kopi robusta dibandingkan dengan Desa lainnya di Kecamatan Panjalu. Jika melihat sejarah perkembangannya, usaha perkebunan kopi rakyat di Desa Kertamandala bukan dirintis oleh masyarakat asli Desa Kertamandala, tetapi oleh masyarakat pendatang yang berasal dari Raja Desa yang pernah bekerja menjadi petani kopi di Lampung. Namun, seiring dengan berjalannya waktu, banyak masyarakat Desa Kertamandala yang mulai tertarik dan pada akhirnya mengembangkan usahatani kopi robusta. Pada perkembangannya, kopi tumbuh menjadi komoditas yang memasyarakat di Desa Kertamandala. Selain didukung budaya tani, juga kondisi alamnya yang subur, karena terletak di kaki Gunung Syawal yang berketinggian sekitar 750-1.779 mdpl. Meskipun cocok juga untuk jenis kopi arabika, namun para petani lebih memilih menanam kopi robusta, karena perawatannya yang lebih mudah. 
Salah satu permasalahan dalam pengembangan kopi kopi robusta di Desa Kertamandala adalah pengetahuan petani dalam pemilihan kualitas mutu kopi dan pemetikan kopi masih lemah.

Petani kopi masih menggunakan beberapa bahan kimia yang mampu merusak tanah dan lingkungan, serta masih bergantung dan menggunakan bahan kimia baik pupuk kimia maupun pestisida kimia dalam jumlah banyak. Hal ini mampu menyebabkan kerusakan baik di tanah maupun lingkungan sekitar lahanusahatani pertanian kopi. Hal tersebut tentunya juga akan berdampak negatif dalam usahatani kopi di masa yang akandatang.

Pertanian berkelanjutan adalah pertanian yang berupaya untuk meningkatkan perekonomian masyarakat setempat dari hasil usahatani tersebut dan menjaga kondisi sumberdaya biologis. Menurut Salikin (2003) dalam Sukma (2017) diperlukan paling tidak tujuh macam kegiatan untuk mencapai tujuan pertanian berkelanjutan, yaitu: 1) Meningkatkan pembangunan ekonomi; 2) Memprioritaskan kecukupan pangan; 3) Peningkatkan pengembangan sumber daya manusia; 4) Meningkatkan harga diri; 5) Memberdayakan dan memerdekakan petani; 6) Menjaga stabilitas lingkungan (aman, bersih, seimbang, diperbarui), dan;
7) Memfokuskan tujuan produktivitas jangka panjang.

Penelitian ini bertujuan untuk :

1. Mengetahui pendapatan usahatani petani kopi sebagai wujud keberlanjutan ekonomi di Kecamatan Panjalu Kabupaten Ciamis.

2. Mengetahui proses regenerasi petani kopi di Kecamatan Panjalu dalam melakukan praktik usahatani sebagai wujud berkelanjutan secara sosial.

3. Mengetahui praktik pertanian organik pada usahatani kopi di Kecamatan Panjalu sebagai wujud keberlanjutan lingkungan.

\section{METODE PENELITIAN}

Metode yang digunakan dalam penelitian ini adalah metode survei. Sugiono (2014), menyatakan bahwa metode survei merupakan metode penelitian yang digunakan untuk mendapatkan data dari tempat tertentu yang alamiah (bukan buatan), tetapi peneliti melakukan perlakuan dalam pengumpulan data, misalnya dengan kueisioner, dan sebagainya.

Jumlah petani kopi di Desa Kertamandala sebanyak 225 orang. Penentuan sampel menggunakan rumus Slovin dengan tingkat kesalahan 15 persen, maka diperoleh ukuran sampel sebanyak 
37 orang (petani kopi). Penentuan sampel dilakukan dengan menggunakan simple random sampling. Menurut Sugiyono (2014), Simple Random Sampling adalah pengambilan anggota sampel dari populasi yang dilakukan dengan cara acak tanpa memperhatikan lapisan yang ada dalam populasi itu.

Data yang dikumpulkan dalam penelitian ini berupa data primer dan data sekunder. Data primer adalah data yang didapat sendiri dengan melakukan pengamatan secara langsung ke lokasi penelitian serta hasil wawancara terhadap responden (dengan panduan kuesioner). Data sekunder diperoleh dengan teknik dokumentasi, yaitu teknik pengumpulan data yang berasal dari berbagai arsip tertulis yang dimiliki oleh instansi-instansi terkait penelitian (Abdurrahman dan Muhidin, 2011).

Pada penelitian ini peneliti menggunakan simple rndom sampling. Menurut Sugiyono (2014), Simple Random Sampling adalah pengambilan anggota sampel dari populasi yang dilakukan secara acak tanpa memperhatikan strata yang ada dalam populasi itu.

Besaran sampel ditentukan berdasarkan persamaan Slovin sebagai berikut:

$$
n=\frac{N}{1+N(e)^{2}}
$$

Keterangan:

$\mathrm{n}$ : Sampel yang ditentukan

$\mathrm{N}$ : Jumlah populasi di daerah penelitian

e: nilai kritis (batas ketelitian) yang diinginkan (persen kelonggaran ketidak telitian karena kesalahan pengambilan sampel populasi). Interval keyakinan yang digunakan dalam penelitian ini sebesar 90 persen.

Jumlah petani kopi di Desa Kertamandala adalah sebanyak 225 orang dengan tingkat kesalahan yang ditolelir adalah sebesar 15 persen maka dengan rumus di atas dapat diperoleh sampel sebagai berikut:

$$
n=\frac{N}{1+N(e)^{2}}
$$

$$
n=\frac{225}{1+225(0,15)^{2}}
$$

$$
n=\frac{225}{1+225(0,0225)}
$$

$$
n=\frac{225}{1+5,0625}
$$

$$
n=\frac{225}{6,0625}
$$


$n=37,11$ dibulatkan menjadi 37 orang.

Tujuan penelitian pertama dianalisis secara deskriptif menggunakan rumus NPV (Net Present Value)

Net Present Value menunjukkan manfaat bersih yang diterima dari suatu usaha pada tingkat suku bunga tertentu. Suatu bisnis dikatakan layak jika penerimaan yang didapat lebih besar dari biaya yang dikeluarkan. Tiga kriteria kelayakan berdasarkan NPV yaitu (Gittinger 2008) :

$$
N P V=\sum_{t=0}^{t=n} \frac{B_{t}-C_{t}}{(1+i)^{\mathrm{t}}}
$$

Keterangan:

$\mathrm{Bt}=$ Penerimaan total pada tahun sekarang (Rp/tahun)

$\mathrm{Ct}=$ Biaya total pada tahun sekarang (Rp/tahun)

$\mathrm{T}=$ Tahun investasi (tahun)

I = Suku bunga discount factor(\%)

Dengan kriteria sebagai berikut:

- Apabila NPV bernilai positif (+), maka usaha menguntungkan dan layak untuk diusahakan.
- Ababila NPV bernilai negatif (-), maka usaha tidak menguntungkan dan tidak layak untuk diusahakan.

Keberlanjutan usahatani kopi ditinjau berdasarkan tiga aspek yaitu aspek ekonomi, aspek sosial dan aspek lingkungan. Keberlanjutan usahatani kopi diukur dengan menggunakan indeks keberlanjutan. Rumus indeks keberlanjutan adalah sebagai berikut.

Indeks keberlanjutan $=\frac{\text { skor yang diperoleh }}{\text { skor maksimum }} \times 100 \%$

Indeks keberlanjutan dibagi menjadi empat kategori status keberlanjutan sebagai berikut (Thamrin et al,2007).

1. $0-25,00 \%$ : Tidak berkelanjutan.

2. $25,01-50,00 \%$ : Kurang berkelanjutan.

3. 50,01-75,00\% : Cukup berkelanjutan.

4. $75,01-100,00 \%$ : Berkelanjutan.

\section{HASIL DAN PEMBAHASAN}

\section{Identitas Responden}

Tingkat pendidikan petani di Desa Kertamandala yang menjadi responden masih tergolong rendah. Petani kopi robusta di Desa Kertamandala didominasi oleh lulusan Sekolah Dasar (SD) yaitu sebanyak 28 orang atau 0,76 persen dari jumlah responden.

Sebagian besar responden berada pada kelompok usia produktif (15-64), yaitu sebanyak 30 orang (81,08 persen) 
yang menunjukkan bahwa responden masih memiliki kemampuan fisik dalam melaksanakan usahataninya.

\section{Analisis Biaya Produksi Usahatani Kopi}

Biaya usahatani kopi memiliki komponen biaya usahatani yang terdiri atas biaya tetap dan biaya variabel. Hasil penjumlahan dari biaya tetap dan biaya variabel disebut biaya produksi atau biaya total dari usahatani kopi.

Untuk lebih jelasnya rincian biaya produksi usahatani kopi di Desa Kertamandala dalam satu kali musim tanam dapat di lihat pada Tabel 1.

Tabel 1. Rata-rata Jumlah Biaya Produksi Usahatani Kopi di Desa Kertamandala

\begin{tabular}{lll}
\hline No & Komponen Biaya & $\begin{array}{c}\text { Jumlah Biaya } \\
(\text { Rp) }\end{array}$ \\
\hline 1. & Biaya Tetap & 14.779 \\
& -PBB & 3.835 .555 \\
& -Penyusutan Alat & \\
2. & Biaya Variabel & $173.955,45$ \\
& -Herbisida & $1.118 .118,82$ \\
& -Kandang & $468.427,27$ \\
& -Urea & $468.427,27$ \\
& -Ponska & $12.137 .591,82$ \\
\hline & -Tenaga Kerja & $\mathbf{1 8 . 2 1 6 . 8 5 5}$ \\
\hline
\end{tabular}

Tabel 1 menujukan rata-rata biaya produksi usahatani kopi per hektar per satu kali musim tanam yang dikeluarkan oleh petani adalah sebesar Rp.18.216.855

\section{Pendapatan Usahatani Kopi}
Tabel 2. Rata-rata Jumlah Biaya, Penerimaan dan Pendapatan Usahatani Kopi di Desa Kertamandala.

\begin{tabular}{llc}
\hline No & Uraian & Jumlah (Rp) \\
\hline 1. & Penerimaan & 26.176 .800 \\
2. & Biaya Total & $\underline{18.216 .855-}$ \\
3. & Pendapatan & 7.959 .945 \\
\hline
\end{tabular}

Tabel 15 menujukan bahwa pendapatan petani kopi di Desa Kertamandala Kecamatan Panjalu Kabupaten Ciamis memperoleh pendapatan dari usahatani kopi per musim panen adalah sebesar Rp.7.959.945. Hal ini sejalan dengan hasil penelitian Ronaldo (2017) yang menunjukan tinggi rendahnya pendapatan petani tergantung pada produksi kopi, harga jual dan biaya yang dikeluarkan selama proses produksi. Pendapatan adalah hasil pengurangan antara total penjualan dengan total biaya produksi yang dikeluarkan petani mulai dari persiapan hingga panen. Pendapatan pada usahatani diartikan sebagai selisih antara besarnya penerimaan dan biaya yang di keluarkan (biaya total) (Supriyadi A,2014).

\section{Net Present Value (NPV)}

Perhitungan NPV dilakukan untuk mengetahui manfaat bersih yang diperoleh selama periode kegiatan usaha tani 
(Nurmalina et al. 2010). Perhitungan nilai NPV dapat dilihat pada Tabel 3

Tabel 3. Analisis Kelayakan Net Present Value (NPV)

\begin{tabular}{llll}
\hline Tahun & NCP & $\begin{array}{l}\text { Faktor } \\
\text { PV }\end{array}$ & PV \\
\hline 1 & 7.959 .945 & 0,961 & 7.649 .507 \\
\hline & & NVP & 7.649 .507 \\
\hline
\end{tabular}

Sumber: Data Primer diolah, 2020

'Berdasarkan pada hasil perhitungan, Nilai NPV yang diperoleh dari kegiatan usahatani kopi di Desa Kertamandala di tahun ini mendapatkan mamfaat bersih sebesar Rp7.649.507;-. Hasil perhitungan $N P V$ diperoleh nilai positif, maka kegiatan usahatani kopi di Desa Kertamandala di tahun ini layak untuk dilaksanakan karena menghasilkan $N P V$ lebih besar dari nol $(N P V>0)$.

\section{Praktik Usahatani Berkelanjutan}

\section{Secara Ekonomi}

Data pada tabel 4 menunjukkan hasil rata-rata skor penilaian praktik usahatani kopi yang berkelanjutan secara ekonomi.

\section{Tabel 4. Rata-Rata Skor Penilaian Praktik Usahatani Secara Ekonomi di Kecamatan Panjalu}

\begin{tabular}{|c|c|}
\hline No Indikator & Skor \\
\hline $\begin{array}{l}1 \text { Produktivitas usahatani } \\
\text { kopi }\end{array}$ & 2,43 \\
\hline $\begin{array}{l}2 \text { Kemudahan dalam } \\
\text { memperoleh informasi } \\
\text { pasar berupa harga kopi } \\
\text { yang sedang berlaku }\end{array}$ & 1,78 \\
\hline
\end{tabular}

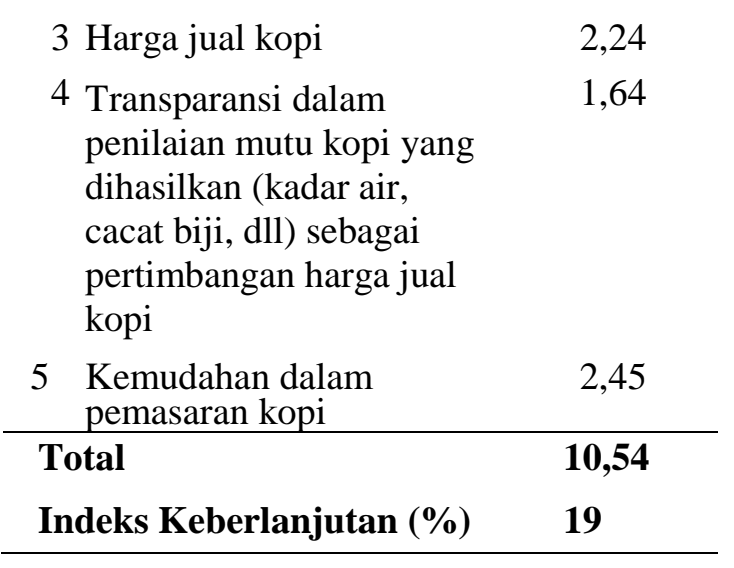

Tabel 4 menunjukan bahwa terdapat dua indikator yang sangat sensitif terhadap penilaian praktik usahatani secara ekonomi. Petani kopi Desa Kertamandala masih kesusashan dalam memperoleh informasi pasar berupa harga kopi yang sedang berlaku dikarenakan ketertutupan informasi dari tengkulak dan akses ke tengkulak yang lumayan jauh. Petani terkadang merasakan transparansi harga jual kopi, namun tergantung dengan tengkulak yang dipilih oleh petani. Ada tengkulak yang melihat berdasarkan kadar air kopi, namun ada beberapa yang tidak. Petani akan mendatangi tengkulak bila ingin menjual kopi, sehingga petani juga mengeluarkan biaya untuk pengangkutan.

\section{Praktik Usahatani Berkelanjutan Secara Sosial \\ Tabel 5 menunjukkan rata-rata skor penilaian praktik usahatani kopi yang berkelanjutan secara sosial. Petani tergabung di dalam kelompok tani akan}


tetapi keaktifan dalam kelompok tani masih kurang. Hal ini menyebabkan tidak adanya kegiatan yang dapat membantu petani untuk menambah pengetahuan tentang budidaya kopi. Petani mengikuti kelompok masyarakat seperti kelompok arisan dan kelompok pengajian. Petani juga aktif dalam mengikuti kegiatan gotong royong di daerah lingkungan sekitar tempat tinggal. Anak berusia di bawah 15 tahun (atau dalam usia wajib sekolah) di lingkungan sekitar tempat tinggal petani mayoritas bersekolah serta jarang ada yang bekerja di kebun sebagai buruh tani.

Tabel 5. Rata-Rata Skor Penilaian Praktik Usahatani Secara Sosial di Kecamatan Panjalu

\begin{tabular}{cc}
\hline Indikator & Skor \\
\hline
\end{tabular}

Masyarakat

1 mengikuti kelompok tani 2,41

2 Keaktifan dalam mengikuti 1,91 kegiatan kelompok tani

3 Mengikuti kegiatan kelompok 2,37 masyarakat

4 Jumlah kelompok masyarakat 2,08 yang diikuti

$5 \quad$ Keaktifan dalam mengikuti kegiatan kelompok masyarakat

6 Keaktifan dalam kegiatan gotong royong di lingkungan sekitar

Hak Masa Kanak-Kanak dan Pendidikan

1 Apakah anak usia $<15$ tahun di lingkungan sekitar bersekolah

2 Apakah anak usia $<15$ tahun di lingkungan sekitar menjadi buruh tani

Kesehatan dan Keselamatan Kerja

1 Memiliki alat pelindung diri

2 Penggunaan alat pelindung diri saat bekerja di kebun
3 Pembeersihan limbah yang ada

2,29 setelah Bekerja

\begin{tabular}{ll}
\hline Total & 25,49 \\
Indeks Keberlanjutan (\%) & 44 \\
\hline
\end{tabular}

\section{Praktik Usahatani Berkelanjutan Secara Lingkungan}

Data pada tabel 6 menunjukkan hasil rata-rata skor penilaian praktik usahatani kopi yang berkelanjutan secara lingkungan.
Tabel 6. Rata-Rata Skor Penilaian Praktik Usahatani Secara Lingkungan di Kecamatan Panjalu

\begin{tabular}{l|l}
\hline Indikator & Petani \\
& Sertifikas \\
& i \\
\hline & Skor \\
\hline
\end{tabular}

Konservasi Keanekaragaman

Hayati

1 Yang dilakukan bila melihat $\quad 2,39$ satwa liar di kebun

2 Melakukan langkah dan1,76 tindakan konservasi dengan cara menanam bermacam tanaman tumpang sari/naungan di kebun

Penggunaan Pestisida

1 Pengendalian hama, penyakit 2,5 dan gulma di kebun

2 Menggunakan sistem $\quad 1,77$ pengendalian hama terpadu (PHT)

Konservasi Tanah

1 Kebun pernah mengalami erosi 2,5

2 Membuat terasering di kebun $\quad 1,76$

Sumber Air

1 Sumber air di dekat kebun dijaga2,5

2 Menggunakan air dengan efisien 1,76

Air Limbah

1 Tempat membuang air bekas $\quad 2,5$ cucian sprayer pestisida

2 Tempat membuang air limbah $\quad 1,77$ rumah tangga

Total 21,21 
Indeks Keberlanjutan (\%) 37

Tabel 6 menujukan bahwa petani membiarkan satwa liar apabila berkeliaran di kebun. Ada sebagia petani yang melakukan konservasi keanekaragaman hayati dengan cara menanam lebih dari satu macam tanaman naungan dan tanaman sampingan, yang hasilnya membantu menambah pendapatan petani. Dalam pengendalian hama, tidak banyak petani yang dapat menggunakan sistem pengendalian hama terpadu (PHT) dikarenakan kurangnya pengetahuan petani terhadap pengetahuan budidaya kopi dan pengendalian hama terpadu. Pada penggunaan air, petani kopi di Desa Kertamandala mulai mengurangi guna mengefisiensikan air supaya dapat digunakan untuk keperluan lainnya. Dilain sisi, masih banyak petani yang belum mempunyai tempat khusus untuk pembuangan limbah rumah tangga, masih banyak yang membuang limbah rumah tangga ke sungai, kebun atau tanah dikarenakan masih belum mempunyai fasilitas yang mumpuni.

\section{Keberlanjutan Usahatani}

Keberlanjutan usahatani kopi ditinjau berdasarkan tiga aspek yaitu aspek ekonomi, aspek sosial dan aspek lingkungan. Keberlanjutan usahatani kopi diukur dengan menggunakan indeks keberlanjutan, dengan 5 indikator tentang manfaat ekonomi, 11 indikator tentang manfaat sosial, serta 10 indikator tentang manfaat lingkungan. Petani kopi Desa Kertamandala memiliki indeks keberlanjutan aspek ekonomi, sosial dan lingkungan sebesar 33 persen. Hal ini sejalan dengan penelitian Thamrin et al, (2007) menyatakan bahwa jika nilai indek keberlanjutan berada pada presentase 25,01-50,00 persen termasuk kedalam Kurang berkelanjutan (kurang). Artinya usahatani petani kopi Desa Kertamandala tergolong dalam kategori kurang berkelanjutan. Petani masih tergolong kurang berkelanjutan, karena praktik usahatani kopi secara ekonomi masih ada kendala dalam pengetahuan tentang budidaya kopi, dan Transparansi dalam penilaian mutu kopi yang dihasilkan (kadar air, cacat biji, dll) sebagai pertimbangan harga jual kopi yang akan di jual oleh petani. Dalam aspek sosial petani kopi Desa Kertamandala tergabung di dalam kelompok tani akan tetapi keaktifan dalam kelompok tani masih kurang. Hal ini menyebabkan tidak adanya kegiatan yang dapat membantu petani untuk menambah pengetahuan tentang budidaya kopi. Dalam aspek lingkungan petani kopi Desa Kertamandala masih menggunakan 
herbisida dalam jumlah banyak dan penggunaan air yang belum efisien. Berikut adalah rata-rata nilai indeks keberlanjutan usahatani kopi di Desa kertamandala Kecamatan Panjalu Kabupaten Ciamis.

Tabel 7. Rata-Rata Nilai Indeks Keberlanjutan Usahatani Kopi di Desa Kertamandala Kecamatan Panjalu Kabupaten Ciamis

\begin{tabular}{lll}
\hline $\begin{array}{l}\text { Indeks } \\
\text { Keberlanjutan }\end{array}$ & hasil & Persentase \\
\hline Ekonomi & 391 & 19 \\
Sosial & 945 & 44 \\
Lingkungan & 791 & 37 \\
\hline jumlah & 2127 & $100 \%$ \\
\hline Rata-rata & $\mathbf{7 0 9}$ & $\mathbf{3 3}$ \\
\hline
\end{tabular}

\section{KESIMPULAN}

Produksi dan pendapatan usahatani kopi di Desa Kertamandala Kecamatan Panjalu Kabupaten Ciamis per hektar dalam satu kali proses produksi rata-rata memperoleh pendapatan sebesar Rp. 7.959.945;-. Nilai $N P V$ yang diperoleh dari kegiatan usahatani kopi di Desa Kertamandala di tahun ini mendapatkan mamfaat bersih sebesar Rp7.649.507;--. Hasil perhitungan NPV diperoleh nilai positif, maka kegiatan usahatani kopi di Desa Kertamandala di tahun ini layak untuk dilaksanakan karena menghasilkan $N P V$ lebih besar dari nol $(N P V>0)$.
Praktik usahatani kopi berkelanjutan secara sosial di Desa Kertamandala Kecamatan Panjalu Kabupaten Ciamis termasuk dalam kategori kurang berkelanjutan karena anak berusia di bawah 15 tahun (atau dalam usia wajib sekolah) di lingkungan sekitar tempat tinggal petani mayoritas bersekolah serta jarang ada yang bekerja di kebun sebagai buruh tani. Hal ini menunjukan bahwa regenerasi petani di Desa Kertamandala Kecamatan Panjalu kurang.

Praktek pertanian organik pada tanaman kopi di Desa Kertamandala Kecamatan Panjalu belum sepenuhnya terealisasi karna petani masih menggunakan pupuk kimia dalam budidaya kopi.

\section{Saran}

Untuk meningkatkan pendapatan petani dan harga jual kopi pihak petani harus mengetahui cara dan pemahaman mengenai cara pengolahan kopi yang baik dan benar agar petani kopi bisa menjual kopi dengan haarga yang lebih tinggi. Hal ini sebaiknya dibantu dan didukung oleh pihak kelompok tani dan juga para penyuluh agar anggota petani nya bisa meningkatkan pendapatan dan juga bisa memajukan kelompok tani itu sendiri..

\section{DAFTAR PUSTAKA}

Badan Pusat Statistik 2018. Provinsi Jawa Barat Dalam Angka. Jawa Barat. 
Gittinger JP. 2008. Analisa Ekonomi Proyek-Proyek Pertanian. Jakarta (ID):UIPress.(2):57-69.

Mubyarto. 1984. Pengantar Ekonomi Pertanian, Edisi 3. Jakarta: LP3ES.

Santoso, B. 2016. Pendugaan Fungsi Keuntungan dan Skala Usaha pada Usahatani Kopi Rakyat di lampung
Jurnal Penelitian Agro Ekonomi, 6(1-2),

Sugiono. 2014. Metode Penelitian Bisnis Alfabeta. Bandung.

Supriadi, Agus dkk. 2014. Analisis Pendapatan Usahatani Kopi Rakyat di Kecamatan Limbangan Kabupaten Kendal. Universitas Wahid Hasyim. Semarang. 